Екатерина Деминиева

\title{
ДЕТИ МИГРАНТОВ В ШКОЛАХ ТОМСКА И ИРКУТСКА: ПРОБЛЕМЫ АДАПТАЦИИ И МЕРЫ ВКЛЮЧЕНИЯ В ШКОЛЬНОЕ ПРОСТРАНСТВО
}

\begin{abstract}
В статье анализируются вопросы, с которыми сталкиваются школы при появлении в них детей мигрантов, а также меры, которые предпринимают местные власти, администрация школ и учителя для работы с этой категорией учеников. Обозначены причины, по которым в городах появляются особые «мигрантские школы», а в некоторых школах «мигрантские» классы. Ситуация анализируется на примере нескольких школ Томска и Иркутска, в которых проводилось исследование в 2018-2019 гг. По мнению учителей и администрации основная проблема, с которой они сталкиваются - это незнание русского языка учениками, приезжающими их других стран. Несмотря на то что количество таких учеников в классах небольшое, отсутствие уроков русского языка для иностранцев заставляет учителей полагаться на различные стратегии для интеграции этих детей. В Томске местные власти адаптировали программу для детей с особенностями развития для включения в нее детей мигрантов. В других случаях школы или учителя стараются выходить на контакт с местными диаспорами, которые организовывают уроки русского языка для детей иностранцев. В российских школах ожидают от детей мигрантов полной ассимиляции. При этом нагрузка по содействию в ней ложится на плечи учителей, которые пытаются разными способами разрешить этот вопрос. У них не хватает ни времени, ни возможностей работать с детьми в этом направлении. Они считают, что именно родители должны обеспечивать детям дополнительные занятия и адаптировать их к школьной жизни. Попадая в школу, ребенок из мигрантской среды должен, как они считают, соответствовать определенным стандартам. Таким
\end{abstract}

Екатерина Борисовна Деминцева- к. и.н., заведующая Центром качественных исследований Института социальной политики, доцент, Школа культурологии, Национальный исследовательский университет «Высшая школа экономики», Москва; Лаборатория социально-антропологических исследований, Томский государственный университет, Томск, Россия. Электронная почта: edemintseva@hse.ru 
образом, школа не готова принимать то разнообразие, которое привносят дети мигрантов в ее пространство. Помощь школам в работе с детьми мигрантов со стороны государства помогла бы создать более комфортные условия и для учителей, и для учеников.

Ключевые слова: «мигрантские» школы, «мигрантские» классы, дети мигрантов, адаптация, интеграция

DOI: 10.17323/727-0634-2020-18-4-673-688

Появление детей мигрантов в городах и школах России- относительно новая тема для российских исследователей (Омельченко и др. 2010; Александров и др. 2011; Солдатова 2014; Demintseva 2020). Трудовая миграция из бывших советских республик началась в 1990-2000 гг., а семейная, в которую были включены дети, стала заметна в 2010 г. (Флоринская 2012). Появление детей трудовых мигрантов в российских школах стало вызовом для учителей и местных властей.

Первые постсоветские потоки мигрантов в Россию из бывших республик были в основном русскоязычными, а школы в странах СНГ в 1990-е гг. еще учили детей по программам, аналогичным российским. В эти годы, дети, приезжавшие в Россию, сталкивались, как правило, с теми же трудностями адаптации в школе, как и любые другие школьники, приезжавшие их соседних городов или областей. Специальные программы, направленные на адаптацию детей и обучению их русскому языку, появились позже, в 2000-е гг. Например, в Москве созданы Школы русского языка (ШРЯ) в которых проходили занятия по обучению русскому языку и подготовке детей мигрантов к школе. Однако из 12 школ, располагавшихся в тот момент во всех округах Москвы, не осталось ни одной из-за отсутствия финансирования (Арефьев 2015).

Ситуация изменилась в 2010-е гг. В страну стало приезжать много семей, русский язык для которых не был родным. Школы оказались не готовы к появлению новых учеников в школьном пространстве. Одного-двух таких детей в классе школьная администрация рассматривала как исключение и решала вопросы, связанные с обучением ребенка и его адаптацией к российской школьной системе индивидуально (Александров и др. 2011; 2015). Со временем учеников, приехавших из других стран, оказывалось больше. Исследования насчитывают 7-9 учащихся в начальных классах и 5-7 в средних и старших (Деминцева и др. 2017). В некоторых школах появляются классы, в которых оказывается еще больше детей мигрантов, чем в других, и их количество в одном отдельном классе параллели может достигать двух третей.

Несмотря на больший приток мигрантов, не говорящих по-русски, в России нет государственных программ, которые ориентированы на адаптацию учеников из других стран в школьном пространстве, а также уроков, 
обучающих их русскому языку (Александров и др. 2012; Деминцева и др. 2017): «Единого инструктивного документа, который бы целевым образом регулировал вопросы обучения детей из семей иноэтничных мигрантов в Российской Федерации, на данный момент не существует» (Омельченко 2018:324). Как правило каждый регион или город сами решают, как проводить работу в школах, направленную на адаптацию детей мигрантов (Омельченко и др. 2010; Засыпкин и др. 2013; Вандышев и др. 2013).

Необходимо отметить, что бэкграунд у таких детей может быть различным. Одни приехали в Россию непосредственно перед поступлением в школу, некоторые из этих детей не говорят по-русски. Приезжающие в среднюю школу подростки могут не только не знать русского языка, но и отставать по российской школьной программе. Другие дети рождены в России, посещали детские сады, хорошо говорят по-русски и включены с первых дней в жизнь класса. Часть детей имеют российское гражданство (Александров и др. 2015; Деминцева и др. 2017). Как показывают наши предыдущие исследования, дети, владеющие языком, не испытывают особых проблем с адаптацией в школе (Деминцева и др. 2017). Но, что важно для данного исследования, учителя и родители воспринимают как детей мигрантов, прежде всего, тех, кто внешне отличается от «русского» большинства. Поэтому часто в категории «дети мигрантов» оказываются выходцы из стран Средней Азии, Кавказа, в том числе и дети, приехавшие из кавказских республик России (Demintseva 2020).

Исследования в Москве и Санкт-Петербурге показали, что чаще всего дети мигрантов попадают в школы «со сложным социальным контекстом» (Александров и др. 2011; 2012; Деминцева и др. 2017). Ни в Москве, ни в Санкт-Петербурге нет специальных образовательных программ, которые направлены на эту категорию учеников несмотря на то, что и родители, и администрация школ говорят о детях мигрантов как о проблеме. В исследованиях, проведенных в Москве и Подмосковье, я попыталась выяснить, как администрация школ и учителя приспосабливаются к появлению этой категории учеников, какие стратегии предпринимают для их адаптации (Деминцева 2020; Demintseva 2020). В этой статье анализируются проблемы, с которыми сталкиваются школы Томска и Иркутска. Какие меры предпринимают местные власти, администрация школ и учителя для работы с этой категорией учеников? Существуют ли программы на региональном или городском уровне, которые содействуют адаптации детей в школах? Существует ли специфика в этих регионах в контексте появления детей мигрантов в школах?

\section{Теоретическая рамка исследования}

Классическая теория ассимиляции утверждает, что культурная адаптация и структурная ассимиляция два взаимосвязанных процесса. Зная 
язык страны, интегрируясь в ее общество через различные институты, становясь их частью и взаимодействуя с принимающим обществом, мигранты и их дети получают доступ к разного рода ресурсам и становятся менее уязвимыми к дискриминации (Alba, Nee 2009). Однако теория сегментированной ассимиляции, оспаривает этот тезис, поскольку в современном обществе некоторые группы мигрантов в силу своего происхождения и, соответственно, большей дискриминации, не могут полностью интегрироваться в принимающее общество. Само общество держит их на расстоянии, не давая возможности влиться в него.

Исследователи говорят о том, что мигранты используют свой человеческий капитал, поддерживая жизнь в принимающем обществе через этнические сообщества (Portes, Zhou 1993; Portes, Rumbaut 2001). Эта избирательная ассимиляция, при которой мигранты знают язык страны, еe традиции, но при этом сохраняют свой язык, элементы своей культуры в принимающей стране, по мнению ученых имеет ряд преимуществ. Вопервых, поддерживается более прочная связь между родителями и детьми, авторитет родителей для молодых мигрантов продолжает играть важную роль в их жизни (Portes, Rumbaut 2001). Во-вторых, мигранты, как только приехавшие в страну, так и второго поколения, могут иметь больший доступ к ресурсам, которые им предоставляет их этническое сообщество. Что касается второго поколения мигрантов, то более тесная связь с семьей и сообществом может также предотвратить их вливание в «уличные» группировки районных молодежных неформальных объединений (Portes, Fernández-Kelly 2008).

В последние годы группой мигрантов, к которой приковано внимание исследователей, изучающих интеграцию, являются дети. Исследователи подчеркивают, что для детей мигрантов школа является основным местом социализации в новой стране: местом их социальной интеграции, которое дает необходимые ребенку знания для получения образования и дальнейшего трудоустройства (Alba, Holdaway 2013; Heath, Brinbaum 2014). Признано, что для успешной ассимиляции важны две составляющие (Нао, Pong 2008): первая - качество образования, которое предоставляет школа, дополнительные занятия для этой группы учеников, специальные адаптационные программы для детей мигрантов; вторая-демографические характеристики школ. Исследования показывают, что концентрация детей мигрантов в школах, где учатся преимущественно дети из семей с низкими доходами, приводит к получению ими низкого качества образования (Portes, Zhou 1993). Это объясняется ограниченными ресурсами, которые имеют родители как местных детей из низкостатусных семей, так и семей мигрантов (Heath, Brinbaum 2014; Alba, Foner 2015).

Исследователи, изучающие интеграцию детей мигрантов и этнических меньшинств в российских школах, обращают внимание на специфику российского контекста. Во-первых, в отличие от «мигрантских» школ 
в западных странах, которые находятся, как правило, в бедных и «этнических» районах, в России нельзя говорить о существовании городской сегрегации. Речь идет о сегрегации школьной, и такие «мигрантские» школы могут располагаться в разных районах города (Александров и др. 2018; Деминцева 2020). В Москве и Санкт-Петербурге дети мигрантов попадают в школы со «сложным социальным контекстом», в которых учатся дети из семей с низким социальным статусом (Александров и др. 2012; Деминцева и др. 2017). Во-вторых, дети мигрантов часто являются наиболее успешными учениками в своих школах (там же): они мотивированы к учебе, так как их семьи рассматривают приезд в Россию и обучение в российской школе как социальный лифт для своих детей. При этом в этих школах отсутствуют какие-либо адаптационные программы для детей мигрантов, и взаимодействие учеников и учителей происходит скорее исходя из их собственного понимания ситуации и выстраивания отношений между «местными» и «приезжими» (Demintseva 2020; Омельченко 2018).

\section{Методология}

Исследование проводилось в 2018 г. в Томске и в 2019 г. в Иркутске. Информация о школах, в которых учится большее чем в других учебных заведениях города детей мигрантов в Томске предоставлена Региональным центром развития образования, в Иркутске- Департаментом образования. Информация о школах, в которые мигранты отдают своих детей, получена непосредственно от самих трудовых мигрантов, проживающих в городах, с которыми проводились либо полуформализованные интервью, либо беседы в рамках сбора информации по проекту «Использование и создание мигрантами городской инфраструктуры сибирских региональных столиц».

В Томске я посетила две школы, одна из которых находится в центре города (недалеко от центрального рынка), а другая- в окраинном, бывшем «рабочем» районе. В каждой школе проведено по три интервью с учителями, по одному интервью с администрацией школы. Для интервью выбирались учителя, имеющие опыт работы в классах, в которых учится большее количество детей мигрантов, чем в других. В Иркутске так же две школы: первая в центре города (недалеко от торгового центра «Шанхай сити», построенного на месте бывшего стихийного рынка «Шанхайка»), вторая-недалеко от центра, в бывшем «рабочем» районе. Проведено по четыре интервью с учителями, с психологом одной школы и директором другой. Отбирались учителя, имеющие опыт работы с классами, в которых учатся дети мигрантов. В течение двух недель проводилось включенное наблюдение, происходили неформальные беседы с учителями. Также проводились беседы с мигрантами, работающими на рынке рядом с торговым центром. Интервью записаны на диктофон или в полевой дневник. Также в дневнике записаны наблюдения, пересказ бесед с учителями и администрацией. Записанные 
интервью транскрибировались. В статье приводятся цитаты только записанных на диктофон интервью, однако ситуации, описываемые в тексте, проговаривались и во время неформальных бесед. При проведении исследования всем информантам обещана анонимность.

\section{Дети мигрантов в школах Томска и Иркутска}

В Томске и Иркутске есть школы, которые считаются «мигрантскими». Ситуация с их появлением похожа на ту, которую мы наблюдали в предыдущих исследованиях (Деминцева и др. 2017; Demintseva 2020). Две школы, на которые в Томске и Иркутске указали не только местные жители, но и администрация города как на «мигрантские», расположены рядом с большими рынками. В обоих городах эти рынки, расположенные в центре города, являются местами работы многих трудовых мигрантов. В разговорах с учителями и администрацией школы Иркутска, подтверждается наличие в некоторых классах этих школ большого количества детей мигрантов.

В разговорах с владельцами небольших магазинов на рынке я спрашивала о том, где учатся их дети. Многие называли именно эту школу. Причем, некоторые мигранты уже уехали из этого района, сняли более комфортное жилье на окраине, но продолжали возить детей в эту школу. По мнению одного из киргизов, работающих на рынке, в школе знали его семью, семью его брата, детям комфортно учиться. Кроме того, удобно, что дети учились рядом с местом их работы.

Похожая ситуация сложилась со школой, расположенной около центрального рынка в Томске. Многие торговцы говорили о том, что школа находится рядом с местом работы, старались снять квартиру неподалеку. Однако эту школу, в отличие от иркутской, не считают «мигрантской». В ней есть классы, в которых учат польскому и немецкому языку, в старших появляются лицейские классы, она занимает неплохое место в городском рейтинге.

В городах есть еще несколько школ, которые считаются «мигрантскими». Две другие школы (одна в Томске, другая-в Иркутске), расположены не рядом с рынками, но в бывших «рабочих» или «промышленных» районах города. Эти школы еще в советские годы имели репутацию «плохих», в них в основном учились дети из низкостатусных семей. Эта ситуация типична для российских городов. Дети мигрантов, как правило, попадают в школы с «трудным социальным контекстом», те, в которые «местные» родители не хотят отдавать своих детей (Деминцева 2020), негативно реагируют на появление в «хороших» школах детей мигрантов. Как показывают наши предыдущие исследования, администрация идет на поводу у родителей, стараясь сохранить репутацию школы. С другой стороны, родители-мигранты пытаются отдать детей в ту школу, где, по их мнению, учителя понимают, как работать с детьми из других стран. Учитель одной из школ Иркутска объясняет, как появляются «мигрантские» школы: 
...Да, они туда [в школу] идут. Потому что поначалу эта школа брала таких детей, и поэтому они туда шли. В среде их общения они как-то эту информацию передают, и все идут в основном туда (социальный работник, учитель, классный руководитель 8-го класса, Иркутск).

Родители «местных» детей, увидев, что ребенок записан в класс, где учится больше детей мигрантов, чем в других классах, стараются перевести его либо в другой класс, либо в другую школу. Завуч томской школы рассказывает, как родители влияют на формирование классов:

У нас классы «А» и «Б» набираются в первые сутки, как открывается запись. Туда все хотят попасть, кто хочет своим детям образование дать хорошее. Класс «В» еще за весну набираем. А «Г» и «Д» как раз кто в последние дни приходит записываться. Многие мигранты в последние числа августа приходят. Потом некоторые местные родители просят перевести детей в другие классы, так как не хотят в этом классе учиться. В течение года в этот класс попадают те дети, которые не тянут в других. Так и получается этот класс «Д» (завуч, школа, где в параллелях два «мигрантских» класса, Томск).

Таким образом «мигрантская» школа и «мигрантский» класс в Томске и Иркутске- это результат стратегий родителей детей как «местных», так и мигрантов, поддерживаемых школами. Мигранты стараются отдать детей в школу, которая готова с ними работать, в то время как «местные» родители, не скрывают что не хотят, чтобы их дети учились с этой категорией учеников в одном классе, и стараются отделить своих детей от мигрантов. Если школа большая, у нее несколько параллелей, то «местные» родители стремятся к тому, чтобы дети учились только в определенных классах, где нет детей мигрантов. Эта ситуация является типичной для многих российских городов, в том числе для Москвы и Петербурга. Несмотря на то, что Томск и Иркутск не являются основными центрами притяжения мигрантов, здесь тоже можно говорить о выделении детей мигрантов как собой категории и появлении если не школ, то классов, в которых они концентрируются.

\section{Адаптация детей мигрантов в школах}

С появлением детей мигрантов в школах, одной из основных проблем учителя называют незнание русского языка. До поступления в школу некоторые из детей никогда не говорили по-русски. Однако, обозначая эту проблему как основную, учителя отмечали, что детей, совсем не говорящих по-русски, мало, 1-3 ребенка в классе. Эта ситуация создает основную проблему для учителя, который сам должен решить, что делать и как включать этих детей в работу класса. Некоторые учителя выбирают стратегию «работы на сильного ученика». В классе, в котором 28-30 учеников, учитель не может заниматься по отдельной программе с 2-3 
учениками, поэтому во время уроков старается минимально включать их в школьный процесс:

Если бы я набрала один класс мигрантов полностью, то у меня бы дней 10 была бы только подготовка. Больше речевого развития, еще что-то. Если я буду сидеть с киргизами, русские-то дети что будут делать? (учитель младших классов, в котором учится 2/3 детей из семей мигрантов, Иркутск).

Многие учителя стараются решить проблему через родителей: просят их нанять репетитора или логопеда. Но многие родители-мигранты не знают, как найти такого репетитора, а некоторые не могут платить за занятия. Часть учителей работает с такими детьми отдельно, раз или два в неделю встречаясь с ними на дополнительных занятиях после уроков. Как правило, это бесплатные занятия, учителя проводят их, чтобы помочь ребенку «догнать» свой класс, потому что у ребенка, не говорящего по-русски, первый год обучения - это «год молчания» (Деминцева и др. 2017). Дети не могут говорить с одноклассниками, не понимают части урока, у учителя нет времени для их подготовки:

Но вот, допустим, в прошлом году у меня был случай: девочка приехала из Киргизии, < ..>, вроде бы старательный ребенок,- она там [в Киргизии] училась где-то в лицее или в гимназии, у нее были там хорошие оценки, пятерки и так далее. А здесь ей тяжело. <..>, а здесь не получается, и она старается. И на уроках она не может ответить. И стихотворение на литературе отвечать ей тоже сложно, потому что она не все может сказать. Вот в этом плане, конечно, с точки зрения детей, им сложно. С точки зрения преподавателей, тоже сложно, потому что на уроке мы не имеем возможности объяснить то, что детям русскоязычным понятно изначально (учитель русского языка, работает с 5-8 классами, Иркутск).

Как говорят сами учителя, дети «выравниваются» через 1-2 года, в зависимости от того, смогли ли им помочь, но обычно помощь происходит за стенами школы.

Проблемы, возникающие в школе в связи с присутствием детей мигрантов, связаны и с тем, что существует единый стандарт оценивания для всех учеников. Попадая в школу, ребенок включается в образовательную систему, которая предполагает, что каждый ученик должен соответствовать этому стандарту, и его уровень оценивается контрольными работами. Зная эту систему и работая в ней, учителя рассматривают детей исходя из этого «стандарта». То, что ребенок жил до школы в другой стране и язык является для него вторым, но он может на нем заговорить через несколько месяцев, не является плюсом ребенка. Какие-то недостатки в произношении, неумение «правильно» говорить по-русски, учителя рассматривают не как этап ассимиляции ребенка, который неизбежен для детей-инофонов, а как его проблему, с которой надо бороться. Даже в классах, в которых учится 
больше, чем в других, детей мигрантов, учителя не готовы принимать этническое многообразие. Большинство ссылаются на необходимость работать по стандарту, заданному системой образования.

В Томске, понимая ситуацию, разработана региональная программа, выделяющая среди школьников детей, которые по каким-то причинам не подходят под «норму». В интервью с учителями, работающими в «мигрантских» классах, появилось понятие «дети с протоколом», таких большинство в «мигрантском» классе. В эту категорию входят те, у кого проблемы с речью, с поведением или еще какими-то особенностями, которые мешают успешной учебе. «Ребенка с протоколом» выявляет сам учитель. Он рекомендует школе и родителям отправить ребенка «на комиссию». Комиссия (педагоги, психологи и логопеды города) по результатам обследования присваивает статус, позволяющий ребенку не сдавать стандартные экзамены и учиться в школе с учетом его особенностей. Этот статус подтверждается каждый год, и ребенок может его не получить в следующем году, а продолжить учиться, как большинство школьников.

«Детьми с протоколом» часто становятся дети мигрантов, так как некоторые из них плохо говорят по-русски или с акцентом, плохо читают и отстают по программе. Такой ребенок автоматически исключается из списка учеников, сдающих экзамены, чтобы не снижать рейтинг класса и школы. «Протокол» оказался удобен и для учителей, и для родителей мигрантов. Родители отмечают, что, во-первых, дети меньше напряжены в школе и спокойно учатся, не опасаясь очередной контрольной. Во-вторых, они получают бесплатное питание, а для мигрантов это большая помощь, в особенности если у них несколько детей: «Многие родители детей мигрантов хотят, чтобы ребенку дали этот статус, дети всегда накормлены, к ним меньше придираются. Пока никто не говорил, что не хочет этого» (учитель начальных классов, Томск).

Не имея адаптационных программ и возможности выделить ребенкаинофона, чтобы он мог обучаться по особой образовательной траектории в школе, правительство области утвердило программу, которая обходит понятие «ребенок-инофон» или «ребенок из семьи мигрантов», а выделяет его как ребенка, не соответствующего «норме». Таким образом ни в одной из школ не только нет адаптационных программ, но и дети мигрантов не выделяются как ученики, которым нужен особый статус в силу незнания русского языка. Администрация и учителя видят в присутствии детей мигрантов в школе одну из проблем, которую решают разными способами, в том числе выделяя детей как особую категорию, не учитывая при этом их происхождение.

\section{Проблемы обучения}

Обсуждая тему детей мигрантов в школах, администрация и учителя, с одной стороны, подчеркивают разнообразие этой категории, с другой, 
пытаются найти единое решение проблем, связанных с адаптацией детей. Разнообразие видится учителям не только в этническом происхождении, но и в различных миграционных траекториях семей, их социальном статусе. При более детальном рассказе о классе, учителя говорят о разнообразии историй семей мигрантов: одни приехали и осели; есть те, кто только привез детей, кто стремиться в данный момент включиться в принимающее общество. Учителя обращали внимание, что меньше всего проблем с теми детьми, которые до школы посещали детский сад в России. По мнению учителей важной проблемой является не «культурная разность», а простое незнание языка. Они отмечали, что, как только ребенок начинал говорить по-русски, исчезали проблемы во взаимодействии с учениками и учителями в пространстве школы, многие подчеркивали, что он становился «таким же, как все».

Несмотря на понимание учителями разнообразия историй детей, они считают, что основной формой взаимодействия с такими учениками должно быть создание отдельных классов, с реализацией программы по русскому языку как иностранному. Эта тема была особенно актуальна для учителей младших классов, которые работали на протяжении четырех лет с одной и той же группой детей: «У меня было и 20 с лишним киргизов, и больще. Так вот, этих киргизов надо бы в нулевой класс сажать. Вот им нулевка, а потом первый, и тогда было бы вообще все отлично» (учитель младших классов, 2/3 класса мигранты, Иркутск). На сегодняшний день такая форма работы с детьми мигрантов видится многим учителям начальной школы наиболее оптимальной формой работы. Во многом это связано с тем, что у них нет надежды на введение специальных адаптационных программ для детей мигрантов или уроков русского языка для иностранцев.

Поскольку учителя не видят помощи со стороны департамента образования, они надеются получить ее от родителей и, возможно, от условного «мигрантского сообщества». Так, социальный работник в одной из иркутских школ, сказала, что направляет детей, плохо говорящих порусски, в «школу при местной мечети» (которой, по факту, не существует) и на курсы при иркутском университете. Университетские курсы существовали два года, но потом закрылись. К моменту разговора с учителем их не было около двух лет. Только в одном случае учитель младших классов в процессе поиска возможных мест обучения детей русскому языку, познакомилась с преподавателями кафедры «русский язык как иностранный» в иркутском университете, окончила курсы для преподавателей и стала вести кружок для детей мигрантов в своей школе. Но такие случаи проявления инициативы единичны. Как правило эти курсы не оплачиваются, а кружки ведутся на общественных началах: «Я сейчас для своих детей веду "Развитие речи". За свой счет, за счет своего здоровья. Не оплачивается это все, раз в неделю оставляю мигрантов и поехали! С первого класса» (учитель начальных классов, Иркутск). 
В Томске также большинство инициатив учителей являются частными. Учитель «мигрантского» класса одной из школ познакомилась с главой местной киргизской диаспоры и предложила родителям детей мигрантов посещать в Доме дружбы курсы русского языка для детей, организуемые диаспорой. Учителя пытаются найти выход, подключая свои связи или взаимодействуя с теми организациями и частными лицами, которые могут помочь. Но это остается лишь частной инициативой. Поэтому учителя считают, что выходом является объединение этой группы детей в отдельные классы и организация отдельной работы.

Помимо отсутствия адаптационных программ, дополнительных уроков русского языка как иностранного в школах, у учителей нет времени, чтобы дополнительно работать с детьми. Несмотря на это они стараются придумать занятия в рамках бесплатных кружков или же за счет своего личного времени, которое они могут проводить в школе. Таким образом, вопреки ограничению по времени и отсутствию в программе уроков русского как иностранного, учителя по мере возможности стараются помочь детям и самим себе, так как не видят другого выхода для решения возникших проблем.

\section{Заключение}

В последние годы появляется все больше семей мигрантов с детьми школьного возраста, которых не замечает министерство образования (Омельченко 2018). Наше исследование показало, что дети мигрантов являются, с одной стороны, проблемной категорией для школ, а с другой«невидимой» группой. Для детей мигрантов нет специальных программ или дополнительных уроков русского языка, хотя они в них нуждаются. Проблемы, с которыми сталкиваются иркутские и томские школы похожи: отсутствие понятной для администрации и учителей государственной политики в отношении детей мигрантов, адаптационных программ и дополнительных уроков русского языка. Отсутствие уроков «русского как иностранного» заставляет учителей предпринимать самостоятельные меры, чтобы помочь и детям, и себе.

На понимание школы как стандартизированного пространства, в котором дети должны соответствовать определённым нормативам (как образовательным, так и культурным) влияет образовательная политика государства. Попадая в эту среду, ребенок должен соответствовать стандарту. Сегодня школа не готова принимать то разнообразие, которое привносят дети мигрантов в ее пространство. Во внимание не принимается, что они могут не говорить по-русски или русский язык не является им родным. Вследствие этой политики единообразия возникают региональные программы, подобные томской, когда признается, что ребенок в силу специфики своего опыта не попадает под «норму». 
В российских школах от детей мигрантов ожидают полной ассимиляции. При этом нагрузка по ее осуществлению ложиться на плечи учителей. Поскольку у учителей не хватает ресурсов для работы с детьми мигрантов, они надеются на помощь родителей. Те, кто общается с детьми мигрантов, знают, что связь с этническим сообществом предоставляет им дополнительные ресурсы. Однако это редко учитывается учителями и администрацией школ. Зачастую проблем, связанных с детьми мигрантов, предпочитают не замечать, хотя открытость учебных заведений новым ресурсным взаимодействиям сделала бы сосуществование всех участников школьного пространства более комфортным.

\section{Выражение признательности}

Исследование проведено при финансовой поддержке Российского научного фонда (проект № 18-18-00293).

\section{Список источников}

Александров Д., Баранова В., Иванюшина В. (2011) Дети из семей мигрантов в школах Санкт-Петербурга. Предварительные данные. СПб.: Издательство Политехнического университета.

Александров Д., Баранова В., Иванюшина В. (2012) Дети и родители-мигранты во взаимодействии с российской школой. Вопросы образования, (1): 176-199.

Александров Д., Иванюшина В., Казарцева Е. (2015) Этнический состав школ и миграционный статус школьников в России. Bопросы образования, (2): 173-195.

Александров Д., Тенишева К., Савельева С. (2018) Дифференциация школьного выбора: два района Санкт-Петербурга. Вопросы образования, (4): 199-229.

Арефьев А. (2015) Вопросы обучения детей из семей иностранных граждан в Москве. Вестник РУДН: Вопросы образования, (5): 149-159.

Вандышев М., Прямикова Е., Чудинов А. (2013) Проблем и перспективы обучения детей из семей мигрантов Свердловской области. Педагогическое образование в России, (4): 26-31.

Деминцева Е., Зеленова Д., Опарин Д., Космидис Е. (2017) Возможности адаптации детей мигрантов в школах Москвы и Подмосковья. Демографическое обозрение, (4): 80-109.

Деминцева Е. (2020) От «заводской» до «мигрантской» школы: (пост)советская школьная сегрегация в городском пространстве. Laboratotium, 12 (1): 152-182.

Деминцева Е., Пешкова В. (2014) Мигранты из Средней Азии в Москве. Демоскоп Weekly. Доступно по ссылке: http://demoscope.ru/weekly/2014/0597/tema01.php (дата обращения: 1 марта 2020). 
Засыпкин В., Зборовский Г., Шуклина Е. (2013) Дети мигрантов в Северном регионе: социологический анализ проблем социокультурной адаптации. Вестник Сургутского Университета, 2 (23): 143-150.

Омельченко Е. (2018) Интеграция мигрантов средствами образования: российский и мировой опыт. М.: Этносфера.

Омельченко Е., Андреева Ю., Лукьянова Е., Сабирова Г., Крупец Я. (2010) Адаптация детей мигрантов в школе. Методическое пособие: рекомендации по проведению комплекса адаптационных мероприятий в общеобразовательных учебных заведениях $P Ф$. Ульяновск: Издательство Ульяновского государственного университета.

Солдатова А. (2014) Опыт этнологического изучения школьных систем в полиэтничных мегаполисах (подходы и практики обучения детей этнических меньшинств в Москве, Лондоне и Мехико): дис. канд. истор. наук. М.: Издательство Московского университета.

Флоринская Ю. (2012) Миграция семей с детьми в Россию: проблемы интеграции (по материалам социологических опросов центра миграционных исследований). Проблемы прогнозирования, (4): 118-126.

Alba R., Foner N. (2015) Strangers No More: Immigration and the Challenges of Integration in North America and Western Europe. Princeton: Princeton University Press.

Alba R., Holdaway J. (2013) The Children of Immigrants at School: A Comparative Look at Integration in the United States and Western Europe. New York: NYU Press.

Alba R., Nee V. (2009) Remaking the American Mainstream: Assimilation and Contemporary Immigration. Cambridge, MA: Harvard University Press.

Demintseva E. (2017) Labour Migrants in Post-soviet Moscow: Patterns of Settlement. Journal of Ethnic and Migration Studies, 43 (15):2556-2572.

Demintseva E. (2020) 'Migrant Schools' and the 'Children of Migrants': Constructing Boundaries around and Inside School Space. Race, Ethnicity and Education, 23 (4):598-612.

Hao L., Pong S. L. (2008) The Role of School in Upward Mobility of Disadvantaged Immigrants' Children. The ANNALS of the American Academy of Political and Social Science, 620 (1): 62-89.

Heath A.F., Brinbaum Y. (2014) Unequal Attainments: Ethnic Educational Inequalities in Ten Western Countries. Oxford: Oxford University Press.

Portes A., Fernández-Kelly P. (2008) No Margin for Error: Educational and Occupational Achievement among Disadvantaged Children of Immigrants. The ANNALS of the American Academy of Political and Social Science, 620 (1): 12-36.

Portes A., Rumbaut R. G. (2001) Legacies: The Story of the Immigrant Second Generation. Berkeley: University of California Press.

Portes A., Zhou M. (1993) The New Second Generation: Segmented Assimilation and Its Variants. The Annals of the American Academy of Political and Social Science, (530):74-96. 
Ekaterina Demintseva

\title{
CHILDREN OF MIGRANTS IN TOMSK AND IRKUTSK SCHOOLS: ADAPTATION AND INCLUSION IN THE SCHOOL SPACE
}

\begin{abstract}
The article explores issues articulated in Russian schools enrolling migrant children, as well as the strategies chosen by local authorities, school administrators and teachers as they work with this category of pupils. The article outlines the reasons why 'migrant schools' and, in some cases, 'migrant classes' appear in two cities. The study on which the analysis is based was conducted in several schools in Tomsk and Irkutsk in 2018-2019. The main problem that teachers face is the limited proficiency in Russian of some students. Even though there are usually only a few such students in any given class, the lack of adaptation programs and Russian language lessons for foreigners forces teachers to rely on their own devices to help these children to adapt. In Tomsk, local authorities adapted a program for children with special needs to include migrant children. Russian schools expect the full assimilation of migrant children. The main work is undertaken by teachers who try in different ways to solve this problem on their own. Today, teachers have neither the time nor the opportunity to work with this category of children. They believe that their parents should arrange additional classes for their children and help them adapt to school life. Once in school, a child from a migrant background is expected to meet rigid standards: the school is not ready to accept the diversity that children of migrants bring to its space. Assistance from the government in terms of work with migrant children would facilitate a more comfortable working conditions for both teachers and students.
\end{abstract}

Keywords: 'migrant' schools, 'migrant' classes, children of migrants, adaptation, integration

DOI: $10.17323 / 727-0634-2020-18-4-673-688$

\section{References}

Alba R., Foner N. (2015) Strangers No More: Immigration and the Challenges of Integration in North America and Western Europe. Princeton: Princeton University Press.

Alba R., Holdaway J. (2013) The Children of Immigrants at School: A Comparative Look at Integration in the United States and Western Europe. New York: NYU Press.

Alba R., Nee V. (2009) Remaking the American Mainstream: Assimilation and Contemporary Immigration. Cambridge, MA: Harvard University Press.

Ekaterina Demintseva-Cand. Sci. (Hist.), Center for Qualitative Research, Institute for Social Policy; School of Cultural Studies, National Research University Higher School of Economics; Laboratory for Social and Anthropological Studies, Tomsk State University, Tomsk, Russian Federation. Email: edemintseva@hse.ru 
Aleksandrov D., Baranova V., Ivaniushina V. (2011) Deti iz semej migrantov v shkolakh SanktPeterburga. Predvaritel'nye dannye. [Children from Migrant Families in Schools in st. Petersburg. Preliminary Data]. St. Petersburg: Izdatel'stvo Politekhnicheskogo Universiteta.

Aleksandrov D., Baranova V., Ivaniushina V. (2012) Deti i roditeli-migranty vo vzaimodejstvii s rossijskoj shkoloj [Migrant Children and Parents in Collaboration with a Russian School]. Voprosy obrazovaniia [Educational Studies], (1): 176-199.

Aleksandrov D., Ivaniushina V., Kazarceva E. (2015) Etnicheskij sostav shkol i migracionnyj status shkol'nikov v Rossii [The Ethnic Composition of Schools and the Migration Status of Pupils in Russia.] Voprosy obrazovaniia [Educational Studies], (2): 173-195.

Aleksandrov D., Tenisheva K., Savel'eva S. (2018) Differenciaciia shkol'nogo vybora: dva rajona Sankt-Peterburga [Differentiation of School Choice: Two Districts of St. Petersburg]. Voprosy obrazovaniia [Educational Studies], (4): 199-229.

Arefiev A. (2015) The Education of Children from Families of Foreign Citizen in Moscow Schools. Vestnik RUDN. Voprosy obrazovaniya [Educational Studies], (5): 149-159.

Demintseva E. (2017) Labour Migrants in Post-soviet Moscow: Patterns of Settlement. Journal of Ethnic and Migration Studies, 43 (15): 2556-2572.

Demintseva E. (2020) 'Migrant Schools' and the 'Children of Migrants': Constructing Boundaries around and inside School Space. Race, Ethnicity and Education, 23 (4):598-612.

Demintseva E. (2020) Ot 'zavodskoj' do 'migrantskoj' shkoly: (post)sovetskaia shkol'naia segregaciia v gorodskom prostranstve [From the 'Factory' to 'Migrant' School: (Post-) Soviet School Segregation in Urban Space]. Laboratotium, 12 (1): 152-182.

Demintseva E., Peshkova V. (2014) Migranty iz Srednei Azii v Moskve [Migrants from Central Asia in Moscow]. Demoscope Weekly. Available at:_http://demoscope.ru/weekly/2014/0597/tema01.php (accessed 2 November 2017).

Demintseva, E., Zelenova D., Oparin D., Kosmidis E. (2017) Vozmozhnosti adaptacii detej migrantov v shkolakh Moskvy i Podmoskov'ia [Opportunities for the Adaptation of Migrant Children in Schools in Moscow and the Moscow Region]. Demograficheskoe obozrenie [Demographic review], (4): 80-109.

Florinskaya J. (2012) Migracia semej s detmi v Rossiu: Problemi integracii (Po materialam sociologicheskih oprosov centra migracionnih issledovanij) [Migration of Families with Children to Russia: Problems of Integration (Based on Surveys of the Center for Migration Studies)]. Problemi prognozirovania [Forecasting problems], (4): 118-126.

Hao L., Pong S. L. (2008) The Role of School in Upward Mobility of Disadvantaged Immigrants' Children. The ANNALS of the American Academy of Political and Social Science, 620 (1): 62-89.

Heath A.F., Brinbaum Y. (2014) Unequal Attainments: Ethnic Educational Inequalities in Ten Western Countries. Oxford: Oxford University Press.

Omelchenko E., Andreeva Yu., Lukyanova E., Sabirova G., Krupets Ya. (2010) Adaptatsiya detey migrantov v shkole. Metodicheskoe posobie: rekomendatsii po provedeniyu kompleksa adaptatsionnykh meropriyatiy $v$ obshcheobrazovatel'nykh uchebnykh zavedeniyakh $R F$ [Adaptation of Migrants' Children in School. The Methodical Manual: Recommendations on Carrying Out of a Complex of Adaptive Measures in Educational Institutions of the Russian Federation]. Ulyanovsk: Izdatel'stvo Ul'yanovskogo gosudarstvennogo universiteta. 
Omelchenko E. A. (2018) Integraciya migrantov sredstvami obrazovaniya: rossijskij i mirovoj opyt [Integration of Migrants Through Education: Russian and World Experience]. Moscow: Ethnosphere.

Portes A., Fernández-Kelly P. (2008) No Margin for Error: Educational and Occupational Achievement among Disadvantaged Children of Immigrants. The ANNALS of the American Academy of Political and Social Science, 620 (1): 12-36.

Portes A., Rumbaut R. G. (2001) Legacies: The Story of the Immigrant Second Generation. Berkeley: University of California Press.

Portes A., Zhou M. (1993) The New Second Generation: Segmented Assimilation and Its Variants. The Annals of the American Academy of Political and Social Science, (530):74-96.

Soldatova A. (2014) Opyt etnologicheskogo izucheniya shkol'nykh sistem v polietnichnykh megapolisakh (podkhody i praktiki obucheniya detey etnicheskikh men'shinstv v Moskve, Londone i Mekhiko): diss. kand. istor. nauk [Experience in the Ethnological Study of School Systems in Polyethnic Megacities (Approaches and Practices of Teaching Children of Ethnic Minorities in Moscow, London and Mexico). PhD Dissertation]. Moscow: Izdatel'stvo Moskovskogo universiteta.

Vandyshev M., Pryamikova E., Chudinov A. (2013) Problem i perspektivy obucheniya detej iz semej migrantov Sverdlovskoj oblasti [Problems and Perspectives of Teaching Children from Migrants' Families in Sverdlovsk Region]. Pedagogicheskoe obrazovanie v Rossii [Teacher Education in Russia], (4): 26-31.

Zasypkin V., Zborovskij G., SHuklina E. (2013) Deti migrantov v Severnom regione: sociologicheskij analiz problem sociokul'turnoj adaptacii [Migrants' Children in Northern Region: Sociological Analysis of Sociocultural Adaptation Problems]. Vestnik Surgutskogo Universiteta [Bulletin of Surgut University], 2 (23): 143-150. 